\title{
American Reincarnations: What the Many Lives of Past Lives Tell us about Contemporary Spiritual Practice
}

\author{
Courtney Bender
}

This paper explores how contemporary "past life" and "reincarnation" practices in the United States draw upon and reproduce visions of divine connection formed in nineteenth-century metaphysical investigations. Drawing on ethnographic fieldwork with spiritual seekers in Cambridge, MA, in 2002-04, I demonstrate how contemporary past life beliefs and practices resonate with older concerns, questions, and understandings of the self in history. These practices allow contemporary American spiritual seekers to augment and creatively rethink (and replace) their relations with intimate others, providing rich experiential resources for placing the self in history and relation. At the same time, these practices displace practitioners' interests in the metaphysical histories that scholars of religion have been most interested in recovering, raising new questions for historians and sociologists alike about how traditions are carried and recognized.

\section{INTRODUCTION}

\section{The CONTEMPORARY AMERICAN new age has been viewed by scholars as a jumble of post-modern religious bricolage built on}

Courtney Bender, Department of Religion, Columbia University, 80 Claremont Avenue, Room 103, New York, NY 10027, USA. E-mail: cb337@columbia.edu. This research was supported by a grant from the Institute for Social and Economic Research and Policy, Columbia University. Many thanks to Jonathan Dworkin, Erika Dyson, and two anonymous reviewers for comments on previous drafts, and to John Modern for coordinating the joint metaphysical submission.

Journal of the American Academy of Religion, September 2007, Vol. 75, No. 3, pp. 589-614 doi:10.1093/jaarel/lfm037

(C) The Author 2007. Published by Oxford University Press, on behalf of the American Academy of Religion. All rights reserved. For permissions, please e-mail: journals.permissions@oxfordjournals.org Advance Access publication on August 7, 2007 
individual seeking, experience, appropriation of "exotic" religious ideas and practices and organized only by individual seekers' whimsy (Donaldson 1999; Lau 2000; Carrette and King 2005). Spiritual practitioners' own claims that their religious paths are governed by personal choice, inspiration and experience generally confirm such interpretations (Heelas 1996; Wuthnow 1998; Roof 1999), resulting in a portrait of the "new age" as a quintessentially modern, cosmopolitan religion built out of ruptures from the past (Hervieu-Leger 2000). Reincarnation and past life beliefs are often noted as representative of modern seeker spirituality's ability to appropriate and refashion religious elements from other sources to their own liking and for their own private use (Walter and Waterhouse 1999; Walter 2000).

Here as elsewhere, scholarly consensus obscures as much as it illuminates. In fact, American reincarnation beliefs are much more complex and storied than such views suggest. As numerous historians have recently shown, much of the contemporary expression and practice of reincarnation and past lives is solidly within the religious genealogies of American spiritual exploration (Fuller 2001; Schmidt 2000, 2005; Albanese 2006). In fact, contemporary reincarnation beliefs and practices owe as much to nineteenth and early twentieth-century interpretations as they do to more contemporary encounters with Asian texts and ideas. Part of this paper's goal is to trace how earlier arguments and visions about reincarnation continue to resonate in the practices of turn of the twenty-first century seekers.

Nonetheless, the academic project of narrating genealogies of American metaphysical reincarnation beliefs and practice raises further questions. Academics who write such histories and articulate these genealogies build on very different practices of past-making than do reincarnation practitioners and metaphysical believers. Given that most contemporary practitioners themselves seem little aware of (and only marginally interested in) the genealogies that historians and religious studies scholars introduce, we might further ask how and in what respects historical projects and practices are relevant to contemporary practitioners. Thus, although historians' projects contribute greatly to our understandings of the place of metaphysical traditions in contemporary America, they also raise further questions about the various pasts that American spiritual seekers themselves understand as authoritative or even relevant to their own religious lives.

This paper focuses less on the theological or ideological content of reincarnation beliefs (that is, varying views of the unconscious, memory, and the nature of the divine) than on the practices through which metaphysical practitioners observe, sense, and know their various 
past lives, and their place within various histories. Numerous scholars have noted how metaphysical ideas as diverse as channeling and "experiencing" contribute to the development of ahistorical, mystical, universal time (Proudfoot 1985; Brown 1994; Bender 2007), and reincarnation practices similarly challenge the authority of material, genealogical history. Reincarnation practices do not, however, simply remove individuals and groups from material history. Rather, these practices can best be seen as supplementing genealogical histories with mystical histories, in ways that place contemporary spiritual practitioners in dynamic relations to multiple pasts. Thus, American reincarnation practices present a uniquely fruitful entry point into considering the complexities of interpreting metaphysical traditions.

This paper proceeds by reflecting on the multiple pasts of past lives in several ways. I begin by tracing the emergence of a progressive, scientific, and social reincarnation that emerged in late nineteenth-century arguments about afterlife, and pay particular attention to the ways that these aspects shaped ways of reading, interpreting, and verifying past lives. As I note, these practices of interpreting and reading past lives favor mystical histories that displace the genealogies of these practices, including the practices that historians and other scholars might use to link past to the present. Given contemporary practitioners' lack of awareness of these histories, I argue that a tradition of American reincarnation practice is passed on not through conscious recognition of religious lineage, but rather through the reproduction of practices. In this case, these practices participate in a "tradition," albeit one that becomes powerful by occluding references to its genealogy. By marking practices as the carriers of tradition, we can think more clearly about the ways that practices of history and past making shape spiritual practitioners' identities as seekers or religious agents (Bakhtin 1981, 1984; Lambek 2003) and likewise consider how these practices of history making themselves carry and shape traditions (Olick 1999; Chakrabarty 2000).

Turning to ethnographic field research conducted in Cambridge, Massachusetts, I then demonstrate how contemporary spiritual practitioners mobilize reincarnation practices that resonate with the ideas, arguments, and concerns of earlier reincarnation proponents. In particular, we hear how ideas of the soul's progress, the role of science in "proving" the existence of past lives, and the tantalizing and powerful ideas of "soul mates" actively shape both the religious selves and worlds that seekers live within, and the types of pasts in which those worlds continue. In turning to these daily uses, we see how the idioms and practices of past lives become engaged with and bound up in genealogies of which practitioners are little aware. Likewise, we see how individuals draw on 
their "mystical" visions of the past to read and evaluate their "genealogical" pasts, and in doing so, open up creative space for practitioners to rethink their position in the world. The "many lives" of Americans' contemporary and historical investigations and explorations into reincarnation theories thus include both the interplay of spiritual practitioners' interpretations of their own "mundane" and "mystical" pasts, and thus reveal the largely unacknowledged but continuing resonance of early twentieth-century metaphysical understandings of history and selfhood. As I note in the conclusion, sustained ethnographic and historical attention to the ways that these prosaic and mystical practices shape "spiritual" selves and their place in relation to America's metaphysical selves raises questions and new possibilities for analyzing contemporary spiritual practice.

\section{AMERICAN REINCARNATIONS: BUILDING METAPHYSICAL PASTS}

American and Continental metaphysical writers began to argue about the possibilities of "regeneration," the transmigration of souls, past lives, and reincarnation in the last decades of the nineteenth century, at a time when the metaphysical heavens were burgeoning with countless ghosts, astral beings, angels, spirit guides, and ascended Masters. The evident impetus for metaphysical interest in reincarnation was the growing popular attention to Asian philosophical and religious texts, carried forward by interpreters as diverse as Emerson and Helena Petrova Blavatsky, Swami Vivekananda, and Yogi Paramhansa (Hanegraaff 1998; Versluis 1993). Reincarnation beliefs took shape within a field already rich both with metaphysical possibilities (Jackson 1975) and with internecine conflicts over their truths (Prothero 1993; Godwin 1994; Albanese 2006). Several related strands of reincarnation ideology took shape in this period, and although they remained related, they were at times quite at odds with each other. The Theosophical position, for example, stressed a universal law of karma that was in line with Blavatsky's rejection of a "personal God," and furthermore summarily rejected the possibility that people could recall past life memories or experiences. Although Blavatsky's writings (1970) on reincarnation influenced the thinking of numerous New Thought writers, Spiritualists, Rosicrucians, and esoteric Christians (Albanese 2006), her strong position on the absence of a personal God and her refusal to allow that past lives could be remembered set her ideas apart from most others'. In contrast, many other writers inspired by Asian texts discovered in reincarnation a progressive and scientific principle 
wherein souls moved toward perfection and union with God through multiple lives, and in which knowledge of past lives would come to play an important role in interpreting the present. The reincarnation that these writers promoted was "peculiarly modern, conforming to the latest findings of modern science and even prefiguring Darwin's theory of evolution" (Jackson 1975: 531).

The emphasis that these writers placed on the progressive and scientific nature of reincarnation was unquestionably shaped by relentless criticisms from both mainstream Christians and other metaphysical believers who viewed reincarnation as a "repulsive ... unnatural" and "loathsome" abomination (Moore 1977; Godwin 1994: 340). To counter these claims, proponents established that reincarnation was discernable in all religious texts (although often not at first blush), and proponents taught their audiences how to discern these truths by analyzing them in light of their own perceptions. While nineteenth-century arguments about reincarnation were far from unified, the elements of progressive or evolutionary reincarnation, the scientific truths, and the central role of soul mates provided discrete resources and practices that worked to bolster claims for its truths, and simultaneously shaped proponents' understandings of their own place in history. Uncovering the esoteric truths of the past through reading, interpreting experiences, and acknowledging soul connections not only "proved" the truths of reincarnation, it also positioned metaphysical believers within universes populated with known souls working together toward perfect union with the infinite.

\section{Progressive Reincarnation, Scientific Veracity, and Soul Mates}

Many early proponents of reincarnation emphasized its natural place within progressive Christianity, and further argued that such truths were evident to all those who read the scriptures in the proper way. As Maitland and Kingsford noted in their lectures on esoteric Christianity, "the doctrine that all creatures whatsoever represent incarnations, though in different conditions, of one and the same universal soul, would not now need to be re-declared" had the Christian tradition not long ago lost their way (1890: 23-24). The different "conditions" of various souls notwithstanding, all souls moved progressively through multiple lives toward union with the divine. The karmic demands of rebirth, in this view, were "grist" that refined souls, as popular New Thought author Charles B. Newcomb opined. "The mills of the gods grind so slowly that the grist of to-day may have been put into the hopper in some incarnation far remote; but doubtless by the man's own hands, for it is only our own grist that comes to us through the mill of life" 
(Newcomb 1900: 110). Nonetheless, most progressive reincarnationists adamantly agreed that each lifetime represented a step closer to spiritual perfection. Thus, even as they noted that the Bhagavad Gita presented evidence of the universal truths of reincarnation, they also held this text at arm's length, criticizing its depictions of reincarnation and its "lack" of understanding of reincarnation's progressive nature. New Thought Writer Paul Tyner was not alone when he criticized "Asian" views that humans could reincarnate as animals. In the world of American, progressive reincarnation interspecies transmigration was an affront and clear evidence of the need to recover the true meaning of karma. $\mathrm{He}$ wrote, the "true meaning of the doctrine ... the human ego can no more retrograde by reincarnating in brute form than, according to the Darwinian theory, man can degenerate into a monkey, or a monkey into a mosquito" (quoted in Jackson 1975: 532). Responding to a query of whether a person could descend rather than ascend on the spiritual path toward union with God, French Spiritist Allan Kardec said "as regards his social position, yes; but not as regards his degree of progress as a spirit" (Kardec [1875] 1976: 532, italics in original). Maitland and Kingsford also averred, arguing, "man ... has a divine spirit; and so long as he is man-that is truly human-he cannot redescend into the body of an animal or any creature in the sphere beneath him, since that would bean indignity to the spirit" (46).

These Asian "corruptions" of the doctrine's truths were generally considered to be the result of debased and degenerate Asian social norms, a charge that was mirrored in reincarnationists' views of the suppression of the doctrine in Christian texts. Proponents worked vigorously to explain that their views on the matter aligned with the universal truths embedded in the Bible and the Bhagavad Gita alike, but doing so demanded interpretive strategies that sought out the "universal" continuities between traditions and at times explicitly rejected material, historical readings. Reincarnationists honed metaphysical reading strategies that allowed them to distinguish the truths of scriptures using esoteric keys that unlocked the true meaning of text. These strategies at times consciously dismissed interpretations that were mired in the material or in "history." Maitland and Kingsford cautioned that the truths of scripture would remain inaccessible to those who remained rooted in the "phenomenal and objective." In contrast, for "those initiated, the mind is no longer concerned with history; the phenomenal becomes recognized as the illusory-a shadow projected by the Real, having no substance in itself" (ix).

Ultimately, these universal truths and metaphysical comparisons encouraged readers to discover the truths of reincarnation within their 
"own" tradition. Writing under the pen name Yogi Ramacharaka, for example, New Thought writer William Walker Atkinson counseled American Christians to seek out the wisdom of the hidden and mystical gospels, established by the Essenes and the Gnostics, and to recover for Christianity this lost, universal wisdom. As the Yogi Ramacharaka explained, readers did not need to look to India for these truths but rather could use the doctrine of reincarnation and karma as a key that would unlock the most mysterious aspects of Christian doctrine. With karma as an orienting guide, he explained, Christians could finally learn that the Virgin Birth referred not to Mary's chaste body but rather to Jesus' uniquely non-reincarnated spirit (Yogi Ramacharaka 1907: 15).

These metaphysical interpretive strategies were particularly amenable to the growing emphasis and interest in the science and psychology of religious experience that flourished at the turn of the century (Moore 1977; Taves 1999; Schmidt 2000; White 2006). Given the growing, widespread interest among metaphysical proponents and liberal Protestants to prove the truths of religions through scientific means and investigation, it is no surprise that reincarnation's proponents claimed that these newly developing techniques would prove the fact of these "universal laws." Echoing numerous others writing in the first decades of the twentieth century, Yogi Ramacharaka claimed triumphantly that emerging theological and scientific methods, namely the "Higher Criticism," the "Criticism of Science" would "prove the truths of [mystical Christianity's] fundamental principles" (267).

As early as the 1860 s, reincarnation proponents identified numerous types of personal perceptions and experiences, and hinted that these experiences presented scientific proof of past lives. Inexplicably strong dreams, déjà vu experiences, unaccountable fears or phobias, and the experience of being inexplicably attracted to a stranger all confirmed their realities. Proponents encouraged individuals to trust these numerous sensations and experiences, and claimed that the most spiritually advanced souls would be able to remember details from their pasts, perhaps due to the soul's proximity to the next spiritual plane. Nonetheless, even the most prosaic experience provided evidence for transmigration and ample material with which to ponder what had happened in past lives that prompted these experiences.

Within this class of potential past life experiences, "soul mate" encounters became the most important and intriguing. Refashioning the Spiritualist notion wherein each soul was complemented and completed by a singular spiritual and physical companion in both life and death (Albanese 1992), reincarnationists' understandings of soul 
mates invoked "life to life" relationships that mattered to one's own destiny. Kardec therefore explained that "chance" encounters were, on the contrary, the ineluctable work of souls searching out their true mates, unbeknownst to the thinking mind. "[T]he attraction resulting from the ties of a former existence is often the cause of the most intimate unions of a subsequent existence.... It often happens that two persons are drawn together by circumstances which appear to be merely fortuitous, but which are really due to the attractions exercised ... by two spirits who are unconsciously seeking each other amidst the crowds by whom they are surrounded" (159). Finding one's soul mate rendered mystical history an unfolding intersubjective and social project. The soul made progress only in the company of true intimates, who took on a variety of roles (lover, friend, teacher, and child) from life to life. Among other things, these ideas strongly suggested that one's true obligations were to one's soul mates, and likewise suggested that those demands and obligations were so strong that they would overcome all obstacles. As Maitland and Kingsford counseled, "[t]rue Love is stronger than a thousand deaths. For though one die a thousand times, a single Love may yet perpetuate itself past every death from birth to birth, growing and culminating in intensity and thought" (308-309).

The tropes and theologies of nineteenth-century reincarnation pursuits continue to resonate (albeit rarely with citations) in contemporary American past life memoirs, autobiographies, and how-to manuals. Before considering how contemporary practices resonate with past theories of spiritual progress, scientific "verification," and the hopes of spiritual intimacy, we turn to twentieth-century strategies that made inquiry into the specifics of past lives possible and likewise deflected attention from nineteenth-century metaphysicals' role in shaping these theories.

\section{From Past Life Sensations to Knowable Pasts}

Most people were only able to access the truths of reincarnation through passing sensations and thoughts, and many reincarnation writers suggested that there was little to be gained from knowing the details of past lives. Yet it was also the case, according to numerous writers, that the most highly progressed souls and spiritual adepts could recall numerous details of their pasts, and often encountered them within trances, dreams, or other meditative states. For such people, knowledge of past lives became valuable tools for claiming spiritual prowess and also for interpreting how the current life marked a spiritual advance over past lives and their accomplishments. For example, Charles 
Fillmore, founder, with his wife Myrtle, of the Unity Church, claimed that he was the reincarnation of the Apostle Paul (Braden 1964; Vahle 2002). This past life experience bolstered Fillmore's spiritual status and allowed Fillmore's biographers to interpret Fillmore's accomplishments as even greater than those of Paul's. With the logic of progressive incarnations operating in full force, Fillmore's life is a referendum on Paul, whose spiritual limitations are read in "hundreds of admissions of his disobedience, weakness, ambition and double-mindedness," all traits that Fillmore had presumably overcome (quoted in Vahle 2002: 65).

While Fillmore's visions suggested that knowing details about past lives might allow people to better comprehend their purpose in this one (Fillmore 1999: 392), trance-channeler and healer Edgar Cayce channeled information about his clients' past lives in order to heal their psychological and relationship problems (Sugrue 1942; Cerminara 1950). Cayce's visions often located important past lives in Atlantis or the far reaches of time, and in comparison with Fillmore's visions were often short on specific details that might place them in "history" (Melton 1994). Nonetheless, Cayce's messages strongly suggested that knowing and understanding the details of karmic connections would result in more fruitful lives in the present and also suggested that it was not only the spiritually advanced who had to gain from interrogations of past lives. Nonetheless, recovering those pasts was not simple, and depended on trances, meditations, and "perceptions" rather than on "scientific" techniques.

Many nineteenth-century reincarnationists claimed that past lives were open to scientific investigation, but the tools for such study remained primarily inductive, and the topic itself gained little interest among psychical researchers. Indeed, the American Society for Psychical Research remained resolutely disinterested in reincarnation well into the twentieth century, owing most likely to the Society's emphasis on testing Spiritualists' claims of life after death, and reincarnation's connection with Theosophy (which the British Society had "exposed" as fraudulent in 1885). The Society's Annals and Proceedings only mention reincarnation in passing in its first few decades, and these references tend to be derogatory and dismissive (e.g., Edmunds 1915). Nonetheless, as hypnosis became used as a psychological tool for curing psychological neuroses in the years after World War I, psychical researchers and amateurs began to "find" that hypnosis could regress individuals past birth and into previous lives. Hypnosis became a viable strategy of "recovering" past lives, and these recovered memories could then be explored and verified through historical investigation (e.g., Bernstein 1956). Memories recovered under hypnosis presented rich 
details that simultaneously healed individuals of neuroses and obsessions and verified the realities of remembered pasts, insofar as memories could be linked to an historical record. Hypnotic technologies presented new ways to uncover and experience pasts that earlier proponents had argued and counseled were lost forever, and thereby democratized past life knowledge. Now everyone, and not only the most spiritually advanced, could uncover their pasts. All the same, hypnosis brought with it the charge and concern that it was nothing more than a parlor trick and a technique that preyed on the preternaturally weakminded, and that it merely brought to life a subconscious, not a past consciousness. Newly emergent practices of learning about past lives sought to answer and fend off some of these problems and criticisms; these practices of verifying past lives actively reinforced the sui generis aspects of past life knowledge and effectively buried the proximate histories of past life investigators in favor of apprehended and experienced pasts.

Mid- and late-twentieth past life experiencers (and hypnotists) simultaneously apprehend the experience of past lives and the possibility of past lives. Cayce's hagiographers, for example, recount how Cayce had never heard even of the possibility of past life recollection until he had one himself (Sugrue 1942; Cerminara 1950). This trope that makes the "experience" of past life experiences the primary source for knowledge about them is repeated in numerous mid- and late-twentieth-century texts (e.g., Bernstein 1956; Fiore 1978; Weiss 1988). In these texts and testimonials, individuals simultaneously apprehend their own pasts and confront the possibility that such pasts are possible. In addition, these books employ perennialist interpretive strategies that share much with earlier metaphysical writers' interpretations of scriptures, and effectively demonstrate to contemporary readers how to verify the "truths" of experiential knowledge.

Brian Weiss's 1988 bestseller Many Lives Many Masters presents a particularly good example of current reincarnation practices, and many of the tropes and practices in his book are mirrored in numerous other contemporary volumes (e.g., Grant and Kelsey 1967; Fiore 1978; Netherton and Shiffrin 1978; Yarbro 1979). The book opens as Weiss, an "Ivy-League trained" psychiatrist, is struggling with a difficult case, namely a patient whose neuroses do not respond to conventional treatments. Failure looming Weiss turns to hypnosis and "in a series of trance states" inexplicably and surprisingly regresses his patient to a past life. Weiss is surprised by this and also, he tells his readers, quite dubious. But he also notes that once his patient recalls the traumatic events of a past life, her symptoms begin to abate. 
Weiss notes his own scientific skepticism and his patient's conservative Catholic beliefs as a way to claim to that neither he nor his patient has either prior interest in or knowledge about past lives. Weiss's patient's "experience" is also his own experience, one that can be dismissed or explored further. Given his patient's diminished neuroses, Weiss tells his readers that he became more and more curious about past lives. Weiss then turns to the printed "historical" and "scientific" and reports that reincarnation is in fact quite a common view among large numbers of religious groups and others. Notably, Weiss's consultation of the historical record remains firmly in the territory of the "West," and he notes no Asian sources or explications of reincarnation in this first book. More typically, he tells readers that "the early church fathers ... [t] he early Gnostics-Clement of Alexandria, Origen, Saint Jerome, and many others ... believed that they had lived before and would again" (35).

As Weiss makes the claim for the science of past lives, his sources and examples resonate with New Thought and Theosophical ideas. Much of Weiss's book is given over to conversations he has with highly evolved "spirit entities" and Masters (10) whom his patient also channels under hypnosis. The Masters have messages for Weiss and explain, with language that resonates with the full spectrum of the nineteenthcentury astral imaginary, that only advanced souls can remember their pasts without assistance (such as hypnosis), that all souls progress (but some faster than others), and that death and history are but illusions.

Weiss's historical sources (in particular, the absence of Asian texts of any kind), his insistence on the progressive nature of reincarnation, and numerous other elements resonate strongly with nineteenth-century reincarnation discourse that he never mentions. Contemporary reincarnation practitioners like Weiss participate in genres and practices that resonate with nineteenth and early twentieth-century emphasis on apprehension, mystical and esoteric readings of history, and practical applications through soul mates connections likewise excludes "mundane" historical understandings of past lives. As in the past, it is in reproducing such practices and the experiences they engender that individuals' reincarnated selves take shape.

\section{LIVING PAST LIVES IN THE PRESENT}

It goes without saying that contemporary past life practices and genres differ from those of the past: among other things, psychological and hypnotic "technologies" make a close reading of previous lives possible, opening up their content for "healing" or "learning" about 
life's purpose. Nonetheless, the desires, arguments, and musings of Newcomb, Atkinson, Kardec, Fillmore, and Blavatsky continue to haunt and shape these contemporary practices; visions of the soul's progression toward perfection within the company of familiar souls continue to shape metaphysical believers' destinies, and the times and spaces in which they are lived out. Past religious concerns continue to shape American spiritualities that are rarely ceded a history (either by scholarly observers or by practitioners themselves). To demonstrate how the past works on the present, I turn now to ethnographic field research among spiritual practitioners in Cambridge, and in particular focus on the interactions among a loosely connected group of spiritual practitioners in Cambridge, who used various practices to individually and collectively explore their "soul connections" and past lives. ${ }^{1}$

Physical reincarnation was a normal and acceptable idea within many of the networks of spiritual practitioners in Cambridge, where I conducted fieldwork in 2001-04. During my fieldwork, I attended numerous public activities, rites, readings, ceremonies, classes, and healing services in order to map contemporary spirituality's social and cultural organization. I also formally interviewed almost seventy participants and spoke with hundreds more. In the field, I often heard people publicly discuss past lives, refer to others' pasts (in joking and serious ways) and draw links between "soul mates" and other soul connections. Although reincarnation was never the central focus of my research, nearly three-quarters of my interview respondents told me about their past lives, with varying degrees of detail. None of the people I spoke with rejected the possibility of physical reincarnation, although a number remarked that it was not part of their current sense of "reality."

In Cambridge, contemporary past life discourse and practice situates people in multiple pasts. Determining or discussing a past life does not merely extend a person's history back in time, it additionally adds another "layer" of mystical history and connection to a person's genealogical history. Most of the people I met were less interested in

${ }^{1}$ The dozen men and women who regularly attended the group were all between 30 and 50 years old and European-American; all had at least a college degree. Most actively participated in several spiritual groups in Cambridge, and three were also active in local Protestant congregations. Concentrating on an interconnected subset of individuals from my larger sample allows me to present a textured depiction of how contemporary past life practices both shape relations among individuals and likewise do so through drawing on and reproducing idioms and ideas central to earlier reincarnationists' writings. For examples of recent sociological texts that employ similar methods, see Moon (2005) and Smilde (2003). All respondent names and some details (including names of past life personae) have been changed. Quotations from audio-taped interviews are represented in italics. Non-italicized quotations are indirect quotations recorded in field notes. 
interrogating the specific details of past lives than in figuring out how their current friends and family members fit (or did not fit) into lifelong networks of "soul mates" and "soul clusters." These activities were far from solitary: indeed, past lives were thoroughly social, and linked individuals in mystical historical connections that subverted and supplemented mundane, genealogical history. While there may indeed be large numbers of Americans who "believe" in reincarnation without engaging in these or similar social practices (as Walter and Waterhouse [1999] suggest), my respondents made reincarnation a social practice with social consequences. The pasts that my respondents evoked were actively lived out in a variety of interpretive practices and link their selves not only to mystical, imagined pasts, but also to the metaphysical pasts I have laid out in the preceding pages.

\section{Discovering Max}

On a soggy morning in October 2002, I settled into Cathy Morton's living room sofa and started to listen the story of her spiritual journey. During two interviews (totaling five hours), she told me about her most recent past life as a German Jewish scientist who had narrowly escaped the Nazis in 1939. Cathy's discovery began with a trance she experienced while providing a Reiki treatment to a cancer patient, an older Jewish woman who had left Europe on the Kindertransport. In the trance she saw her client as a young girl, waving from a train window. From this vantage, Cathy realized

I'm seeing things from the point of view of a man, and he's trying to get his family out. He's saying, 'We must get the children out!'-and I'm thinking, this is English with a German accent. You know, it's like, why am I hearing this in English with a German accent? It doesn't make any sense. But I know that he's a professor, I can see them with their bags. It's not all their worldly goods. It's just some suitcases.... I can tell it's a life or death situation for them, and they're trying to save their lives by getting out of Berlin. I know it is Berlin. And then later on, I see them, in my minds eye, trying to get to a warehouse at night under cover of darkness. And if they get to the warehouse they'll be OK. I don't, didn't know where that was but it was like - a port, a warehouse in a port. Berlin's not a port, but-but it makes sense later. And I'm like, 'Who is this?' And the name Max M-was just in my mind. It's like, somebody told me that's what it was. And I wrote it down.

Cathy dutifully recorded Max's name in her client's chart, even though her client had never heard of a man named "Max M-." Max would turn out to be a person important for Cathy herself: indeed, she 
had been Max, and these memories and encounters were her own. Cathy did not realize this, however. A few months later, Cathy said, she became interested in past lives, having picked up Brian Weiss's books. "I'd read Brian Weiss's books and I said, well, until I experience it, it's not going to be real for me." Cathy decided to visit a hypnotherapist who practiced past life regression therapy and in a series of vivid sessions "returned" to sixteenth-century Switzerland where she had lived as a "healer" before being banished to the woods to die alone and impoverished. Cathy said that merely learning about this past life lifted a "huge weight off her chest," and also explained why in this life she felt compelled to volunteer with "old cranky ladies." Despite these experiences and connections, however, Cathy soon became impatient with her therapist whom Cathy said was less interested in seeking out proof of this healer's existence than in using the story as a pathway to Cathy's improved psychological health.

Despite the huge psychic weight that lifted off Cathy after the recovery of this sixteenth-century memory, Cathy remained dissatisfied. She did not deny the therapeutic value of this experience and like Weiss, she recognized the therapeutic value of these activities. Nonetheless, she was not content to accept the "healing" she experienced as the proof of past lives' realities. Cathy wanted proof that her past lives had been real, and thus started to search for an historical Max. To do so, she investigated both the inner recesses of her memory through self-hypnosis. She learned that Max was married with children, and was a professor. She asked, "a professor of what? And what I got was a professor of semiotics ... I had heard of semiotics but I didn't know what it meant." Cathy started to research German universities before the war, and shared her limited and frustrating findings with the Mystical Experiences Discussion Group, an informal and independent coterie of mystics that she had joined the previous year.

Cathy attended a week-long workshop with Brian Weiss at the Omega Institute, a holistic spa in Rhinebeck New York. After each morning lecture, she retreated to her room to practice past-life regression with her roommate. Cathy "returned" to the train station, "talking in a German accent in English. ... And my roommate asked what's happening. I said, "We have to get the children out." And I started to get-my chest started to tighten and I couldn't breathe, and it was very frightening. She backed away.... She didn't have the confidence to have me process the negative emotions."

Even as Cathy acknowledged that the German accent sounded fake, she also found that feeling Max's anxiety in her body brought a sense of confirmation that she was Max. Having felt Max's feelings, Cathy 
redoubled her interest and desire to discover whether Max had been a real, historical person and verifying his existence became an allconsuming concern. In guided meditations, she would ask "is $m y$ energy-is the energy that's in Cathy the same energy that's in Max?' The answer I got was yes.... So I'm tapping into this other dimension. But I still [didn't] have proof."

Cathy began to search in earnest for historical information about Max. She tried her hand at automatic typing. These searches yielded little in the way of "facts," but she did get more "information" about him. This information would prove important after she learned Max's identity, but in the meantime, she told me, she and her friends at the discussion group were tiring of her search. The group, populated with individuals variously influenced by Spiritualism and Swedenborgianism, gently suggested that Max might be a spirit guide or angel visitor rather than a past life memory, but she persevered.

Returning home from the group, one evening, she glanced through a printed out page of Google "hits" for Max and noticed for the first time a "variant spelling" of Max's last name, one that she had not used before. She rushed to her computer and received over 600 "hits" for "Albert 'Max' M-," a Nobel Prize winning German Jewish scientist and physician who had made a hurried escape to the United States with his wife and children at the onset of World War II. Several Web sites described the family's harrowing journey to the United States. Cathy now had independent evidence of Max's existence, and many of the details fit her memories. With triumph she told me "that was a huge epiphany, it was like: You got this intuitively. It's a real person. He existed." This epiphany of an historical discovery solidified Cathy's belief in her mystical past. Cathy continued to pursue hypnosis to better understand her own past, and likewise continued to read these experiences against what she learned by reading Max's published memoirs, modern German history, and (as far as she was able) some of his scientific papers.

Cathy continued to read her current life in relation to her memories and growing knowledge of Max's, but she did so with a clear understanding that her current life represented a more spiritually enlightened, advanced position than her previous life as Max. Cathy's hypno-therapist asked her about the purpose of Max's life, and she told me "what came to me was something kind of mundane, it wasn't very, particularly spiritual. It was, 'It's OK to run away to save yourself.' I think Max felt very guilty about leaving behind colleagues, students, and you know people of his culture, to die in Germany. I think that really weighed very heavily on him. But what he learned was that it was OK to save 
yourself." Cathy mused, "There's got to be something that he wanted to do that he didn't get to do, or some growth that his soul needs to go through that didn't get addressed in that lifetime. What I feel is for me now is integrating science with faith, because it's my impression that many lifetimes before were spent in spiritual communities. And he had a very scientific and outwardly non-spiritual life."

Cathy claimed that both her memories of Max and her methods of determining that they are past memories arose sui generis: at numerous junctures through her narrative she establishes that neither her knowledge of Max nor her knowledge of past lives could be traced to anything in her "mundane" biography. Both came to her independently of a genealogy that she, or I, might trace, and her practices thus curtail investigation of the religious genealogies that have shaped her understandings about how reincarnation becomes verifiable and valid, and how past lives can be read against the present. In very real ways, her practices work to undo the claims of mundane historical explanations by placing them in conversation with "mystical" histories that can be uncovered only through other means.

This displacement does not mean that Cathy forgot or dismissed her place within more ordinary historical narratives. Nonetheless, Cathy's multiple histories and their effects on her sense of herself can best be interpreted if we decenter "mundane" biological history. Reincarnation practices and their articulation of the realities of mystical histories do not replace mundane history so much as complicate it: reincarnation practitioners, thus, live in multiple pasts and multiple understandings of the present. While Cathy's practices present one way in which pasts are intensely read against the present through hypnosis and text, we can also see similar complications of biography and the past unfolding in more "prosaic" and daily encounters with past lives.

Prosaic Pasts

Cathy investigated her past lives by following the techniques laid forth in Brian Weiss' books. She was highly invested in the process, and spent both money and time to learn hypnosis in order to learn details about her pasts. In contrast, most people I met in Cambridge who talked about (and knew about) their past lives engaged in idioms and practices that would have been more familiar to Kardec or Newcomb. In short, they knew very little about the specifics of their past lives, and experienced these pasts not through intense interrogations like Cathy's but through "sensations" and déjà vu experiences, or by determining that another person was a "soul mate" or other connected soul. In contrast to Cathy's detail-ridden past life, which gained their power in 
Cathy's ability to link details to an external historical record, "soul mate" connections became powerful through social acknowledgment of a soul connection. Among the Cambridge practitioners I met, these two methods of learning about and verifying past lives likewise gave ballast to each other: Cathy's detailed investigations, for example, were taken as proof that less protracted "sensations" and déjà vu experiences could also be connected to an actual, historically verifiable past life. Likewise, the more prosaic "déjà vu" experiences of soul connections reinforced the claims that hypnosis and other techniques were not merely suggestion. Each practice of past life encounter reinforced the other, and in doing so, the metaphysical strategies of the past were likewise reproduced, becoming less evident but nonetheless present aspects of the multilayered and complex pasts in which contemporary metaphysical believers live and act.

I became more aware of the interanimation of these two types of past life experience in the months following my interviews with Cathy. In early December, Cathy called me to report that three single women had appeared at the mystical experiences group the night before. Crystal, Annette, and Marcy had each recently moved to the Cambridge and learned about the group in a local holistic health tabloid. Everyone in attendance remarked on the auspiciousness of their joint appearance, Cathy told me, adding "something drew them all to Cambridge." These women started seeing each other regularly, inviting each other to spiritual activities they attended and hanging out. Cathy often joined them, and in December, they determined in a joint channeling session that Annette had been Max's (Cathy's) wife. Their joint discovery was further bolstered by the revelation several weeks later that Crystal and Marcy had also spent many lives together as friends.

Marcy told us that during an "energy treatment" session, she learned that they had been close friends in many lifetimes, receiving glimpses "like snapshots" of other lives and relations. Crystal had similarly noted a "sensation" which she added was "not just a sensation but a deep knowing." Neither had a clear sense of when these lives had been, but they were certain that they had a "lives long" commitment. After they acknowledged that the sensation had been mutual, Crystal told me, "we've been hanging out and doing lots of things together, and it is just, it's just like-when I am with her, I get this feeling of coming home."

Marcy and Cathy apprehended their past lives through bodily sensations and "deep knowing." Their joint pasts were apprehended together and the "facts" of the past, while murky and lacking in specifics, were over time confirmed and made real through their fast intimacy and strong friendship. For both women, as well as for Cathy and 
Annette, finding a soul connection allowed each to call on the other for favors and emotional support that extended well beyond that of casual acquaintances. These new connections expanded commitments to family beyond those links fashioned in biology and blood, and enfolded new people into stories of (past) consanguinity even as it challenged the dominance of current family ties. Soul connections demanded that these women reinterpret current responsibilities and commitments in light of "lives long" responsibilities. At times they struggled to fulfill the duties they felt to both mystical and mundane families.

Cambridge mystics sometimes told stories about people they knew who had affairs with soul mates and the notion itself elicited a sense of erotic frisson (Dixon 2001), but very few of the people I learned to know well felt compelled to fully disrupt their family life to follow a soul mate. Mystical connections rarely supplanted biological ones: more frequently "soul" connections demanded that practitioners reimagine the "purpose" of a difficult relationship, or the "lessons" that they might learn from it, even though these reinterpretations took place within the comforting (if not yet fully realized) embraced of a mystical soul family. Marcy often spoke about the challenge of learning to practice "loving kindness" to her estranged father and sister, and about her expectations that this practice would be rewarded with more balanced relationships in a future life, even if her love was not reciprocated in this one. In a different way, Annette received a message that her choice to divorce her husband signified a spiritual advancement. Although their attraction to each other had been "lives long," it was more physical than "spiritual." Overcoming it was a sign of personal advance toward spiritual perfection, and girded her on the path to finding a more redeeming soul mate.

One night in the spring, Cathy invited a dozen of the regular discussion group attendees to her house to celebrate the spring equinox. The interlinked play of mystic and biological families played out in the rituals of dinner overshadowed the "ritual event" that took place after dinner in the living room. Cathy's husband was out of town on business and she had dispatched her son to a friend's house. As we waited for the lamb roast to finish, Eric and his wife talked with Doug about their mystical movie club, and Marcy regaled us with stories of her trip to Tunisia. Crystal poured wine and Cathy pulled a strawberry trifle out of the refrigerator, setting it on the dining room table set with fine china and crystal. Anticipating a question Cathy said, "Oh yes, I've made Easter dinner one week early."

The not-quite Easter dinner began as Annette took Cathy's husband's chair at the head of the table and the rest of us flanked this 
mystical couple: Eric sat at Cathy's right in the position of honored guest and his wife next to him. Doug sat next to me on Cathy's left, Marcy and Crystal flanked Annette. Cathy's daughter also sat at the table, a few others filled out the table. More so than the ritual proceedings that took place later in Cathy's living room, this dinner solidified the presence of this "soul cluster" and likely heightened the tensions leading up to its dissolution. For even as Cathy, Crystal, Marcy, and the others usually talked with me about the more friendly and familial aspects of these past life connections, coursing just beneath the surface were thoughts and whispers about more passionate and romantic connections.

The "soul mates" described in Spiritualist, New Thought, and other early twentieth-century literature cultivated ideals of romantic intimacy that have developed into a robust literature of its own. Dozens of best selling books offer advice about how to identify one's soul mate and offer advice (that ranges from the most conservative to the most libertine) on what to do if one is in a relation with someone who is not. Most of the people I met in Cambridge seriously believed that their life could be fulfilled in all respects by a singular soul mate or "twin flame." Not content with good looks or even a physical compatibility, mystics were on the look out for the person who (as Vivica, a thirty-five-yearold yoga instructor put it) "will connect with every part of my soul, not just my brain or my body."

This possibility also harbored the worrisome challenge that current spouses and lovers were not "the one" or, worse, a possible hindrance to spiritual perfection. Yet even as much (past and contemporary) literature mentions this possibility, most of this literature is conservative, and cautions against disrupting current relationships in pursuit of a spiritual twin. Even a disappointing or unhappy marriage might be necessary for spiritual advance, as Edgar Cayce's biographer Gina Cerminara explains. Even though "cosmic law" (karma) makes marriage "less sacrosanct than many people might think," people should nonetheless take seriously any commitments taken in good faith. "The obligations which are [nowadays] so lightly disregarded ... are not merely meaningless; they have their true binding force in the corporate nature of humanity." Individuals "must learn to accept [marriage's] difficulties and frustrations in a sacrificial spirit, realizing that our lesser self is on trial so that our great Self may be born" (Cerminara 1950: 191).

Nonetheless, the real possibilities that a soul connection might be so strong as to make such disruption "unavoidable" fascinated many of my respondents. Cathy, for example, had a respectful and loving 
marriage, but she also told me, and many others, that she "knew" that Eric was her soul mate. She had determined that she had lived "many lives" with Eric, and he apparently shared this view, basing their impression on shared interests, personal "synchronicities," and even biographical parallels. Eric and Cathy had embarked on several successful joint mystical projects, and this pushed Cathy to ponder whether their "work together" was part of something more. She talked to me regularly about whether being spiritually fulfilled would involve more intense involvement with Eric, or whether she should keep her distance. Eventually Cathy decided that her fascination with Eric and their "connection" was counterproductive to their relationship. Nonetheless, the idea that these soul-linked connections were as powerful, and important as filial commitments was not merely imagined: through such links contemporary practitioners lived in expanded pasts wherein they regularly considered the proper scope of spiritual demands on their daily lives.

These considerations were made powerful through acts that traced and conjured contemporary spiritual practitioners' connections within numerous pasts. Although mystical connections were very powerful in the lives of Cambridge's spiritual practitioners, their power often concentrated in their ability to augment and complicate "mundane" family and work relationships. Past lives raised consideration for a set of additional albeit murky identities that were related in equally murky ways, to daily life. Cambridge's mystics live in and through many histories and realms, from the fantastic and mystically recalled to the mundane and physically present.

Nineteenth and early twentieth-century understandings of reincarnation strongly shape these pasts as well, and resonate strongly within the contemporary practice and understanding of new age "past lives" idioms. Cathy, Annette, Eric, Marcy, and the others interacted together in a field of current and past lives that are shaped by an understanding that reincarnation is progressive, that souls reincarnate in clusters or pairs, and that these pasts influence the present in a number of ways. Beyond this, we can also see that contemporary past life practices are shaped by, and reproduce, ways of engaging the past (both historical and mystical pasts) that, like earlier proponents, emphasize sensations and experiences, inductive approaches, as well as adopting the more "scientific" claims of hypnotic regression. Contemporary past life practice and belief notably emerges and is reproduced through engaging in numerous pasts, both marked and occluded, and numerous practices that position reincarnation practitioners in conversation with several interlinking histories. 


\section{CONCLUSION}

Believers in past lives are, not surprisingly, intensely interested in their pasts, even though they are not always interested in the pasts that scholars are most focused on. This paper's ethnographic and historical exploration of the practices of past-making embedded in American reincarnation beliefs calls attention to the complicated projects of narrating stories about contemporary spirituality and analyzing the scope and shape of its practice. At one level, drawing attention to the proximate of occluded pasts of reincarnation belief in the United States (and the continued resonance of these pasts within contemporary practice) calls into question the sociological notions that the "new age" is new and traditionless, or that its traditions are more invented and somehow less authentic than others. This claim in itself is not new, however, and reaffirms what numerous historians of American religion have demonstrated in recent years. This ethnographic account (and the larger project from which it develops) thus presents a case in which we can see these "traditions" circulating, and also calls attention to the ways that metaphysical practices contribute to contemporary practitioners' (and perhaps scholars') amnesia about these traditions. Reincarnation and past life practices (as well as other metaphysical practices) actively contribute to personal and social narratives that displace attention from metaphysical practices' genealogical pasts, in part by placing their "truths" in timeless, perennial stories. The allure of these practices is in part their ability to sustain claims that they are not bound by material, rational history; as a consequence, these practices and their narratives tend to efface their own genealogical narratives, and the authority that such genealogies confer.

All the same, the reincarnation practices of contemporary practitioners do not so much negate "illusory" mundane history (as Maitland and Kingsford demanded) as transform it. Even though the practices of past lives occlude their more proximate genealogical connections to New Thought, Spiritualism, Theosophy, and other traditions, few contemporary or past reincarnation practitioners give up their places within material history, their obligations to regular life and family, or a sense of their life purpose. In fact, it is through encountering "remembered" pasts that practitioners actively come to consider their obligations within "mundane" and everyday life: indeed, in encountering authoritative mystical pasts, my respondents did not find "escape" from the present but rather actively and creatively considered their place in the world. Engaging in past life practices and narratives effectively expanded individuals' and groups' horizons of their obligations to each other. For example, Cathy reads Max's life in ways that 
allow her to meditate on the purpose of her life and to imagine a sustaining moral purpose for her choices; Kardec demands that reincarnation requires that we treat all persons with the respect we accord our closest intimates, and even as Atkinson (as the Yogi Ramacharaka) counsels Christians to look to their "own" Christian history to discover the "timeless truths" of karma. While these engagements may or may not seem reasonable to us, they nonetheless are all practices that open up space for moral creativity by way of repositioning the authority of genealogical history.

These practices interanimate several forms of history and past making practices, and in doing so provide an evocative example through which scholars of American religion might further consider the limits and possibilities of writing about and representing both the genealogies and enchantments that shape American metaphysical traditions, and their contemporary iterations. In this spirit, we might proceed by remaining attentive to the ways in which religious and spiritual pasts are recalled and felt, imagined and forgotten, and likewise remain attentive to the proliferation of "pasts" that take shape within various practices of imagining, remembering, and forgetting. Such an approach does not leave the various practices of past making at the margins of our work, but rather attends to the ways that the past is structured [through ongoing dialogues both "about the particular past," and how "the past can be remembered" (Morson 1994; Olick 1999: 21)] into the center of conversations about religious traditions and their lived histories. Greater attention to the ways that such pasts are interlinked within lived experience will undoubtedly present new critical possibilities for interpreting American spiritualities and their positions within American religious history.

\section{REFERENCES}

Albanese, Catherine

1992

2006

Bakhtin, Mikhail

1981
"On the Matter of Spirit: Andrew Jackson Davis and the Marriage of God and Nature." Journal of the American Academy of Religion 60: 1-17.

A Republic of Mind and Spirit: A Cultural History of American Metaphysical Religion. New Haven, CT: Yale University Press.

"Forms of Time and the Chronotope in the Novel." In The Dialogic Imagination, 84-258. Austin: University of Texas Press. 
1984 Problems of Dostoevsky's Poetics. Minneapolis: University of Minnesota Press.

Bender, Courtney "Touching the Transcendent: On the Status of 2007 Religious Experience in the Study of Everyday Religions." In Everyday Religion: Observing Modern Religious Lives, ed. by Nancy, Ammerman, 201-208. New York: Oxford University Press.

Bernstein, Morey The Search for Bridey Murphy. Garden City, NJ: 1956 Doubleday.

Blavatsky, Helena Petrova 1970

Braden, Charles 1964

Brown, Michael 1994

Carrette, Jeremy and Richard King 2005

Cerminara, Gina 1950

Chakrabarty, Dipesh 2000

Dixon, Joy 2001

Donaldson, Laura 1999

Edmunds, Albert 1915
Karma and Reincarnation. Los Angeles, CA: The Theosophical Company.

Spirits in Rebellion: The Rise and Development of New Thought. Dallas, TX: Southern Methodist University Press.

The Channeling Zone. Cambridge, MA: Harvard University Press.

Selling Spirituality: The Silent Takeover of Religion. London: Routledge.

Many Mansions. New York: William Sloane Associates.

"Translating Life Worlds into Labor and History." Provincializing Europe: Postcolonial Thought and Historical Difference, 72-97. Princeton, NJ: Princeton University Press.

Divine Feminine: Theosophy and Feminism in England. Baltimore, MD: Johns Hopkins University Press.

"On Medicine Women and White Shame-ans: New Age Native Americanism and Commodity Fetishism as Pop Culture Feminism." Signs 24/ 3: 677-696.

"FHW Myers, Swedenborg and Buddha." Proceedings of the American Society for Psychical Research 8: 253-285. 
Fillmore, Charles. The Essential Charles Fillmore: Collected 1999 Writings of a Missouri Mystic. Unity Village, MI: Unity Books.

Fiore, Edith You Have Been Here Before: A Psychologist 1978 Looks at Past Lives. New York: Coward, McCann and Geoghegan.

Fuller, Robert Spiritual But Not Religious: Understanding 2001 Unchurched America. New York: Oxford University Press.

Godwin, Joscelyn 1994

The Theosophical Enlightenment. Albany, NY: SUNY Press.

Grant, Joan and Denys

Many Lifetimes. Alpharetta, GA: Ariel Press.

Kelsey 1967

Hanegraaff, Wouter

New Age Religion and Western Culture. Albany, 1998 NY: SUNY Press.

Heelas, Paul. The New Age Movement. Oxford: Blackwell 1996 Publishers.

Hervieu-Leger, Daniele. Religion as a Chain of Memory. New 2000 Brunswick, NJ: Rutgers University Press.

Jackson, Carl T. "The New Thought Movement and the 1975 Nineteenth Century Discovery of Oriental Philosophy," Journal of Popular Culture 9: 523-548.

Kardec, Allan (pseud. Spiritualist Philosophy: The Spirits' Book. Arno Hippolyte Leon Denizard Press: New York.

Rivail)

$1976(1875)$

Lambek, Michael The Weight of the Past. New York: Palgrave 2003 Macmillan.

Lau, Kimberly New Age Capitalism: Making Money East of 2000 Eden. Philadelphia: University of Pennsylvania Press.

Maitland, Edward and Anna Kingsford The Perfect Way, or, the Finding of Christ. New York: Frank F. Lovell and Company. 
Melton, J. Gordon 1994

Moon, Dawne 2005

Moore, R. Lawrence 1977

Morson, Gary Saul 1994

Netherton, Morris and

Nancy Shiffrin 1978

Newcomb, Charles B. 1900

Olick, Jeffrey 1999

Prothero, Stephen 1993

Proudfoot, Wayne 1985

Roof, Wade Clark 1999

Schmidt, Leigh Eric 2000
"Edgar Cayce and Reincarnation: Past Life Readings as Religious Symbology." Syzygy: Journal of Alternative Religion and Culture 3: 39-50.

"Discourse, Interaction and Testimony: The Making of Selves in U.S. Protestant Dispute over Homosexuality." Theory and Society 24: 551-577.

In Search of White Crows. New York: Oxford University Press.

Narrative and Freedom: The Shadows of Time. New Haven, CT: Yale University Press.

Past Lives Therapy. New York: William Morrow and Company.

Discovery of a Lost Trail. Boston, MA: Shepard and Lee.

"Genre Memories and Memory Genres: A Dialogical Analysis of May 81945 Commemoration in the Federal Republic of Germany." American Sociological Review 64: 381-402.

“From Spiritualism to Theosophy: 'Uplifting' a Democratic Tradition." Religion and American Culture: A Journal of Interpretation 3: 197-216.

Religious Experience. Berkeley: University of California Press.

Spiritual Marketplace: Baby Boomers and the Remaking of American Religion. Princeton, NJ: Princeton University Press.

Hearing Things: Religion, Illusion, and the American Enlightenment. Cambridge, MA: Harvard University Press.

2005 Restless Souls: The Making of American Spirituality from Emerson to Oprah. San Francisco, CA: Harper Collins Publishers. 
Smilde, David "Skirting the Instrumental Paradox: Intentional 2003 Belief Through Narrative in Latin American Protestantism." Qualitative Sociology 26: 313-329.

Sugrue, Thomas

1942

Taves, Ann

1999

Vahle, Neal 2002

Versluis, Arthur 1993

Walter, Tony 2000

Walter, Tony and Helen Waterhouse 1999

Weiss, Brian 1988

White, Christopher 2006

Wuthnow, Robert 1998

Yarbro, Christine 1979

Yogi, Ramacharaka (pseud. William Walker Atkinson) 1907
There is a River. New York: Henry Holt and Company.

Fits, Trances and Visions: Experiencing Religion and Explaining Experience from Wesley to James. Princeton: Princeton University Press.

The Unity Movement: Its Evolution and Spiritual Teachings. Philadelphia, PA: Templeton Foundation Press.

American Transcendentalism and Asian Religions. New York: Oxford University Press.

"Reincarnation, Modernity and Identity." Sociology 35: 21-38.

"A Very Private Belief: Reincarnation in Contemporary England," Sociology of Religion 60/2: 187-197.

Many Lives, Many Masters. New York: Simon and Schuster.

"Minds Intensely Unsettled: Phrenology, Experience and the American Pursuit of Spiritual Assurance, 1830-1880," Religion and American Culture 16/2: 227-261.

After Heaven: Spirituality in America since the 1950s. Berkeley: University of California Press.

Messages from Michael. New York: Simon and Schuster.

Mystic Christianity Or the Inner Teachings of the Master. Chicago, IL: Yogi Publication Society. 